\title{
Impacts of thinning of a Mediterranean oak forest on soil properties influencing water infiltration
}

\author{
Simone Di Prima ${ }^{1,2, *}$, Vincenzo Bagarello ${ }^{3}$, Rafael Angulo-Jaramillo ${ }^{4}$, Inmaculada Bautista ${ }^{5}$, \\ Artemi Cerdà ${ }^{1,6}$, Antonio del Campo ${ }^{5}$, María González-Sanchis ${ }^{5}$, Massimo Iovino ${ }^{3}$, Laurent \\ Lassabatere $^{4}$, Federico Maetzke ${ }^{3}$ \\ ${ }^{1}$ Department of Geography, University of Valencia, Blasco Ibáñez, 28, 46010 València, Spain. \\ 2 Agricultural Department, University of Sassari, Viale Italia, 39, 07100 Sassari, Italy. \\ ${ }^{3}$ Department of Agricultural and Forest Sciences, University of Palermo, Viale delle Scienze, 90128 Palermo, Italy. \\ ${ }^{4}$ Université de Lyon; UMR5023 Ecologie des Hydrosystèmes Naturels et Anthropisés; CNRS ; ENTPE ; Université Lyon 1; 3 rue Maurice Audin, 69518 \\ Vaulx-en-Velin, France. \\ ${ }^{5}$ Universitat Politècnica de València, Research Institute of Water and Environmental Engineering - Re-Forest, Valencia, Spain. \\ ${ }^{6}$ Soil Physics and Land Management Group, Wageningen University, Droevendaalsesteeg 4, 6708PB Wageningen, The Netherlands. \\ Corresponding author. E-mail: sdiprima@uniss.it
}

\begin{abstract}
In Mediterranean ecosystems, special attention needs to be paid to forest-water relationships due to water scarcity. In this context, Adaptive Forest Management (AFM) has the objective to establish how forest resources have to be managed with regards to the efficient use of water, which needs maintaining healthy soil properties even after disturbance. The main objective of this investigation was to understand the effect of one of the AFM methods, namely forest thinning, on soil hydraulic properties. At this aim, soil hydraulic characterization was performed on two contiguous Mediterranean oak forest plots, one of them thinned to reduce the forest density from 861 to 414 tree per ha. Three years after the intervention, thinning had not affected soil water permeability of the studied plots. Both ponding and tension infiltration runs yielded not significantly different saturated, $K_{s}$, and unsaturated, $K_{-20}$, hydraulic conductivity values at the thinned and control plots. Therefore, thinning had no an adverse effect on vertical water fluxes at the soil surface. Mean $K_{s}$ values estimated with the ponded ring infiltrometer were two orders of magnitude higher than $K_{-20}$ values estimated with the minidisk infiltrometer, revealing probably soil structure with macropores and fractures. The input of hydrophobic organic matter, as a consequence of the addition of plant residues after the thinning treatment, resulted in slight differences in terms of both water drop penetration time, WDPT, and the index of water repellency, $R$, between thinned and control plots. Soil water repellency only affected unsaturated soil hydraulic conductivity measurements. Moreover, $K_{-20}$ values showed a negative correlation with both WDPT and $R$, whereas $K_{s}$ values did not, revealing that the soil hydrophobic behavior has no impact on saturated hydraulic conductivity.
\end{abstract}

Keywords: Soil water repellency; Forest soils; Saturated and near saturated hydraulic conductivity.

\section{INTRODUCTION}

In the last years, researchers have reported an increasing need to have more awareness on the intimate link between land use, soil properties and soil hydrological processes (Bens et al., 2006; del Campo et al., 2014; González-Sanchis et al., 2015; Molina and del Campo, 2012). In the Mediterranean ecosystems, special attention needs to be paid to the forestwater relationships due to the natural scarcity of water (Bisantino et al., 2015). Following the Millennium Ecosystem Assessment, adaptive management is a systematic process for continuously improving management policies and practices by learning from the outcomes of previously employed policies and practices. Adaptive Forest Management (AFM) can be viewed as a long duration experiment. The objective of the experiment is to establish how forest resources have to be managed with regard to an efficient use of water. The means to reach this objective is to artificially regulate forest structure and density in order to enhance soil water availability and, consequently, increase tree growth and stand resilience to climate-driven disturbances (fire and drought), while maintaining soil hydraulic properties (del Campo et al., 2014).

In general, there is a need to thinning the Mediterranean forest recovered after one century of abandonment (AlonsoSarría et al., 2016; Cammeraat et al., 2010; Cerdà, 1997) in order to avoid catastrophic forest fires (Keesstra et al., 2016a;
Pereira et al., 2015). The opening of the canopy, due to the removal of a certain number of trees, is an important practice for the management of forests. It results in important modifications of the microclimatic conditions that influence the ecophysiological functioning of trees (Aussenac and Granier, 1988) and it also influences soil-water relationships. For example, a reduction in forest cover can be expected to increase water availability in the soil profile due to the consequent reduction in transpiration and interception (Brooks et al., 2003; González-Sanchis et al., 2015; Hibbert, 1983; Zhang et al., 2001). Gallart et al. (1997), working in a Mediterranean mountain basin in the Pyrenees, observed that the soil profiles in forested areas always had lower water content than did those in cleared areas due to the effects of forest interception. Other possible factors inducing less water in forest soils include root water extraction and transpiration. Mollnau et al. (2014) studied the soil water dynamics under a western juniper (Juniperus occidentalis) woodland and compared their results with those for a site where the woods had been cut down. They also found that the soil moisture content was higher in sites where the tree cover had been cleared. The woodland had a negative impact on deep water reserve recharge due to the high interception rate of the juniper and also to its ability to extract water from deep soil layers.

Soil hydrological processes are known to depend on soil properties that can be expected to vary with the forest 
management (Heiskanen and Mäkitalo, 2002). For example, thinning with land clearing could probably induce lower levels of organic matter content in the soil and hence a poorer aggregation. Therefore, the soil hydraulic properties are expected to vary in forest areas with different management practices and they need to be determined experimentally. Notwithstanding this, little information is available in semi-arid Mediterranean watersheds on the effects of thinning on soil hydraulic properties.

A reason for the lack of information is that the areas to be sampled have generally a limited or difficult access, which precludes intensive field campaigns, notwithstanding that a large number of determinations is required to obtain representative values of soil hydraulic properties at the field scale. Relatively small datasets are easy to obtain but the reliability of the collected data could be considered more or less uncertain. A means to establish the usability of small sample sizes is to check the consistency among the collected information by different experimental methodologies. For example, different infiltration methods and devices, developed in the last decades, appear usable to determine soil hydraulic properties directly in the field with limited experimental efforts (devices, water volumes, run duration) and robust data analysis procedures (Angulo-Jaramillo et al., 2000, 2016; Bagarello et al., 2014; Di Prima et al., 2016; Lassabatère et al., 2006). Field techniques were also commonly used to determine the impact of vegetation and forest management on infiltration (Cerdà, 1997, 1999; Wang et al., 2016).

Water infiltration into the soil also depends on soil water repellency, that is common in forest soils (Cerdà and Doerr, 2007; Keesstra et al., 2016b). In regions with a Mediterranean dry climate, such as eastern Spain, prolonged dry periods and oil or wax-rich vegetation types commonly induce soil hydrophobicity with consequent changes in the dynamics of the hydrological processes as compared with those occurring in non-water repellent conditions (Dekker et al., 2001; García et al., 2005; Verheijen and Cammeraat, 2007). In particular, soils under deep litter or mor-type humus are expected to be particularly water repellent (Doerr et al., 2000), since films of organic compounds can coat soil aggregates (Blanco-Canqui and Lal, 2009; Ellerbrock et al., 2005). Moreover, hydrophobic organic material may improve aggregate stability reducing swelling and destructive forces linked to trapped air (DeBano, 1981). An increasing water repellent behaviour can occur as a consequence of mulching (Blanco-Canqui and Lal, 2009; Blanco-Canqui et al., 2007; García-Moreno et al., 2013; González-Peñaloza et al., 2012; Šimon et al., 2009). Nonetheless, the effectiveness of woody mulches under field conditions remains unclear (Prats et al., 2012). For instance, Shakesby et al. (1996) found their forest residue mulch to be ineffective in inducing soil water repellency at one of the two study sites, whereas Fernández et al. (2011) and Riechers et al. (2008) found that wood chip mulch induced less water repellency than straw mulch.

According to different authors, using a single method to assess soil water repellency could not be sufficient given for example that it can promote preferential flow and by-pass flow that cannot be detected by a drop scale measurement technique as the widely applied water drop penetration time (WDPT) test (e.g., Bachmann et al., 2003; Buczko et al., 2006; Scott, 2000). In such soils, infiltration experiments with a ponded head of several centimeters or a negative applied head of water may lead to different results for soil hydraulic characterization (Ebel and Moody, 2013). While the first method may overwhelm soil water repellency due to a ponded head exceeding the water- entry values, the second one may underestimate water infiltration due to high water-solid contact angles (AnguloJaramillo et al., 2016; Cerdà, 1996; Ebel et al., 2012; Nyman et al., 2010; Wang et al., 1998). Moreover, the hydrological meaning of saturated hydraulic conductivity could be questionable in hydrophobic soils since they exhibit a time variable water repellency and thus could not wet spontaneously (Buczko et al., 2006). These circumstances reinforce the need to establish comparisons between alternative methods for soil characterization.

A comparison between thinning and non-thinning treatments was recently carried out in a natural Mediterranean oak forest, within the public forest La Hunde, Valencia (NE Spain), where an excessive forest density induced water scarcity problems (González-Sanchis et al., 2013). These authors studied the water cycle during the period 2012-2013 and they found that thinning from the original 816 trees per ha to 414 trees per ha induced an increase in water availability in the soil profile. Meanwhile, reducing tree density did not enhance runoff generation and soil erosion rates.

In this study, the two plots established three years ago by González-Sanchis et al. (2013) were sampled with the main objective to determine the impact of thinning on the soil hydraulic properties of a natural Mediterranean oak forest. In particular, the specific objective was to determine soil water repellency, water-stable aggregates and both unsaturated and saturated soil hydraulic conductivity determined using simple and low-cost field infiltration methods, for a thinned and a control plots three years after thinning.

\section{MATERIALS AND METHODS} Study site

The study area consists of two contiguous plots, each of $1800 \mathrm{~m}^{2}$ (Figure 1), located at the headwaters of Rambla Espadilla catchment, within the public forest La Hunde $\left(39^{\circ} 4^{\prime} 50^{\prime \prime} \mathrm{N}, 1^{\circ} 14^{\prime} 47^{\prime}\right.$ ' W, elevation of $1090 \mathrm{~m}$ a.s.1.), Valencia (NE Spain). Each plot is further divided into three blocks. The plots are located in a typical Mediterranean oak forest approximately 60 years old, characterised by Quercus ilex sbsp. ballota in association with other xerophytic species such as Pinus halepensis, Quercus faginea, Juniperus phoenicea and Juniperus oxycedrus. The aspect (NNW) and slope $\left(15^{\circ}\right)$ are the same for both plots (Bautista et al., 2015).

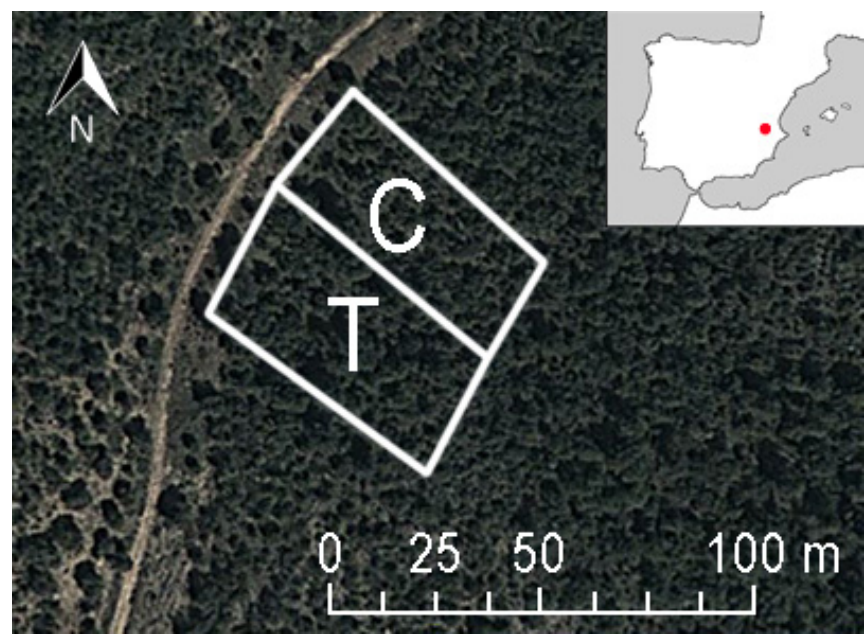

Fig. 1. Aerial view of the experimental site at Monte de La Hunde y Palomeras. Borders of Control (C) and Thinned (T) plots are marked in white. 
The climate is Mediterranean with a mean annual rainfall of $466 \mathrm{~mm}$ and a mean annual temperature of $13.7^{\circ} \mathrm{C}(1960$ 2007). The rainfall was continuously measured by means of a tipping-bucket rain gauge (Davis, USA) programmed to measure at 10-minute intervals, and located in an open area at $20 \mathrm{~m}$ apart from the experimental plots (González-Sanchis et al., 2013). The registered rainfall intensities ranged from 0.28 to $23.1 \mathrm{~mm} \mathrm{~h}^{-1}$, with the most frequent rain intensities (percentiles 0 to 50 ) ranging from 0.28 to $1.2 \mathrm{~mm} \mathrm{~h}^{-1}$. Rainfall intensity of $4.5 \mathrm{~mm} \mathrm{~h}^{-1}$ corresponds to the $90^{\text {th }}$ percentile, while rainfall intensity of $7.5 \mathrm{~mm} \mathrm{~h}^{-1}$ corresponds to $95^{\text {th }}$ percentile. High intensity rainfalls usually occur during springtime (mainly May), and at the end of summer and the beginning of autumn (late August to October). Soil is approximately $30-50 \mathrm{~cm}$ deep in the lower part of the slope and about $10 \mathrm{~cm}$ thick in the higher part, with rock fragments constituting up to $50 \%$ of the soil volume (Bautista et al., 2015).

Because the two plots have the same climate and topographical features, they appear suitable for a comparative investigation of the effects of forest management on soil hydrology. In 2012, the T plot (Figure 1) was thinned, following the Forest Service indications to reduce the forest density from 861 to 414 trees per ha (González-Sanchis et al., 2013; Table 1). The vegetal debris with a diameter lower than $7 \mathrm{~cm}$ was chopped and dispersed on the soil surface of the forest plot (Figure 2). Control (C) plot was not thinned.

Table 1. Mean values of the forest structure variables in the control and thinned plots (from González-Sanchis et al., 2015).

\begin{tabular}{lll}
\hline Forest structure variable & Control & Thinned \\
\hline Density $($ trees ha-1) & 861 & 414 \\
Basal area $\left(\mathrm{m}^{2} \mathrm{ha}^{-1}\right)$ & 11.4 & 9.1 \\
Leaf Area Index $\left(\mathrm{m}^{2} \mathrm{~m}^{-2}\right)$ & 1.8 & 1.1 \\
\hline
\end{tabular}

\section{Soil sampling}

Measurements of soil physical and hydraulic properties were carried out at nine sites within a given plot, following the scheme of González-Sanchis et al. (2015). Briefly, three blocks per plot were established across the main slope. All variables were registered at each block, ensuring a representative number of samples per plot. The litter and leaf residues were gently removed from the soil surface before measurements were made.

Undisturbed soil cores $(0.05 \mathrm{~m}$ in height and $0.05 \mathrm{~m}$ in diameter) were collected at the surface of mineral soil. Nine disturbed soil samples $(0-0.10 \mathrm{~m}$ depth) were also collected in each plot, three per block. The undisturbed soil cores were used to determine the soil bulk density, $\rho_{b}\left(\mathrm{~g} \mathrm{~cm}^{-3}\right)$ and the initial volumetric soil water content, $\theta_{0}\left(\mathrm{~cm}^{3} \mathrm{~cm}^{-3}\right)$. The disturbed soil samples were used to determine organic matter content and water stable aggregates. Three samples per plot (50 g for each sample) were selected to determine the particle size distribution using conventional methods following $\mathrm{H}_{2} \mathrm{O}_{2}$ pre-treatment to eliminate organic matter and clay deflocculation using sodium metaphosphate and mechanical agitation (Gee and Bauder, 1986). In particular, fine size fractions were determined by the hydrometer method, whereas the coarse fractions were obtained by mechanical dry sieving.

According to the USDA standards, the three fractions, i.e., clay $(0-2 \mu \mathrm{m})$, silt $(2-50 \mu \mathrm{m})$ and sand $(50-2000 \mu \mathrm{m})$, averaged for the two plots were $30.1,33.2$ and $36.7 \%$, respectively (corresponding standard deviations $=3.1,8.5$ and 7.8, respectively), and the soil of the studied area was classified as

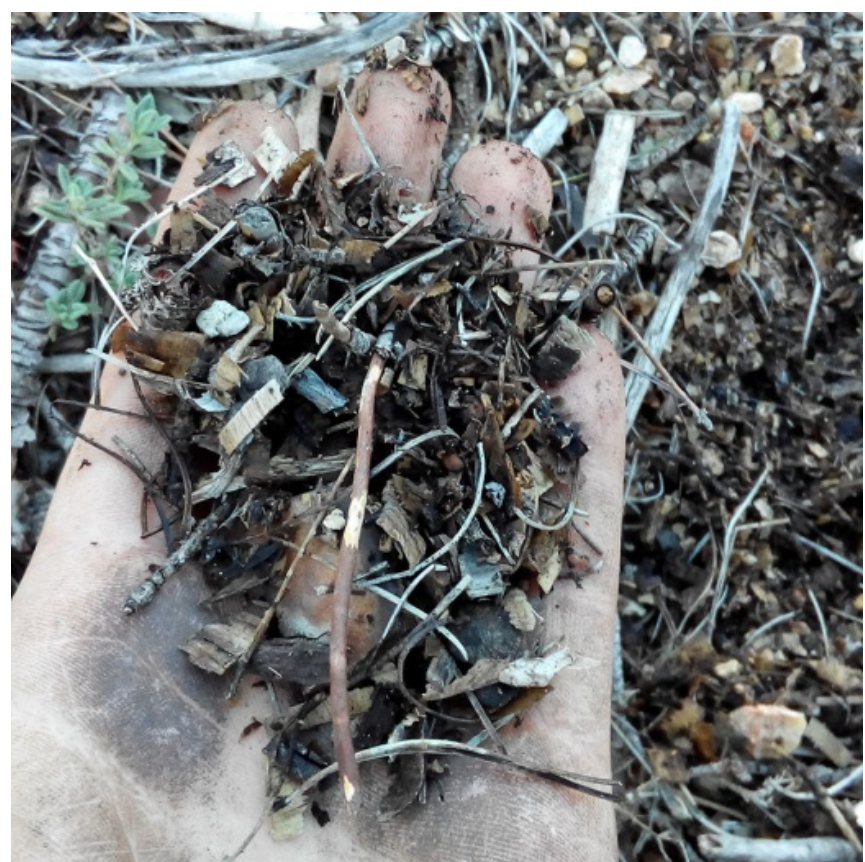

Fig. 2. Mulches obtained from vegetal debris whose diameter was lower than $7 \mathrm{~cm}$ and dispersed at the thinned plot during the treatment in 2012.

clay loam (Gee and Bauder, 1986). The organic carbon content, TOC $\left(\mathrm{g} \mathrm{kg}^{-1}\right)$, was determined by the Walkley-Black method (Nelson and Sommers, 1996). Water repellency tests and infiltrometer measurements were carried out on selected dates during the December 2015 to April 2016 period to explore a wide range of initial soil water conditions.

\section{Surface wettability}

Soil surface wettability was determined at 16 sampling points (eight per plot) using the water drop penetration time (WDPT) test (Wessel, 1988). This test is one of the most widely used methods for quantifying the persistence of soil water repellency (Doerr et al., 2000). It comprises placing ten drops $(0.05 \mathrm{~mL})$ of distilled water on a representative soil surface at a small distance (i.e. a few $\mathrm{cm}$ ) one to another and measuring the actual time until complete infiltration of each drop. The litter and leaf residues were gently removed from the soil surface before measurements were made. At each sampling point, a representative WDPT value was obtained by averaging the ten WDPT measurements. This test is widely used in Mediterranean rangelands as it is easy to perform and allows the comparison in paired plots such as the ones used here (Benito Rueda et al., 2016; Bodí et al., 2013; Dlapa et al., 2013; Keesstra et al., 2016b). Recording of WDPT was stopped after 3600 s, although some drops did not infiltrate during this time interval. In such cases, a WDPT value of $3600 \mathrm{~s}$ was assigned (Buczko et al., 2006).

\section{Mini disk infiltrometer runs}

The mini-disk infiltrometer (MDI) was used to estimate the unsaturated soil hydraulic conductivity (MDI Model S; Decagon Device Inc., 2014). This portable infiltrometer (326-mm high) can easily be used on mountain slopes with small water volumes (50-90 $\mathrm{mL}$ per measurement) and established pressure heads at the infiltrometer base variable in the range -5 to -60 mm (Moody et al., 2009). 
In this investigation, the pressure head on the porous disk of the device, having a diameter of $45 \mathrm{~mm}$, was set at $-20 \mathrm{~mm}$ to exclude the largest pores, i.e. with diameters $>1 \mathrm{~mm}$ (Watson and Luxmoore, 1986), from the three-dimensional infiltration process. Soil hydraulic conductivity corresponding to a pressure head of $-20 \mathrm{~mm}, K_{-20}\left(\mathrm{~mm} \mathrm{~h}^{-1}\right)$, was calculated according to the method proposed by Zhang (1997) and recommended by Decagon Device Inc. (2014). After the infiltration run, we excavated the sample area to check the depth and breadth of wetting front migration.

\section{Index of water repellency}

The index of water repellency, $R$, was evaluated as suggested by Tillman et al. (1989) from the sorptivity of water, $S_{w}(\mathrm{~mm}$ $\left.\mathrm{h}^{-1 / 2}\right)$, and ethanol, $S_{e}\left(\mathrm{~mm} \mathrm{~h}^{-1 / 2}\right)$, using the following relationship (Hallett et al., 2001):

$$
R=\left(\frac{\mu_{e}}{\mu_{w}} \frac{\sigma_{w}}{\sigma_{e}}\right)^{1 / 2}\left(\frac{S_{e}}{S_{w}}\right)
$$

where, the first term is a multiplier $(=1.95)$ accounting for differences in the surface tension, $\sigma\left(\mathrm{N} \mathrm{m}^{-1}\right)$, and dynamic viscosity, $\mu\left(\mathrm{N} \mathrm{s} \mathrm{m}^{-2}\right)$, between ethanol and water and by assuming $\sigma$ values of 0.073 and $0.023 \mathrm{~N} \mathrm{~m}^{-1}$ (at $20^{\circ} \mathrm{C}$ ) and $\mu$ values of 0.0010 and $0.0012 \mathrm{~N} \mathrm{~s} \mathrm{~m}^{-2}$ (at $20^{\circ} \mathrm{C}$ ) for water and ethanol respectively (Tillman et al., 1989). Ethanol is assumed to perfectly wet hydrophobic media because of the soil-liquid contact properties. So, in non-repellent soil, the repellency index cannot be greater than 1.95. Tillman et al. (1989) defined soil with $R>$ 1.95 as subcritically water repellent. According to Lichner et al. (2007), MDI data were used in the field to estimate sorptivity of water and ethanol from the slope of the linear relationship describing cumulative infiltration vs. squared root of time measurements in the early stage of the infiltration process. At each sampling point paired infiltration tests were carried out on the soil surface with water and ethanol at close locations.

\section{Water-stable aggregates}

Water-stable aggregates were determined according to Kemper and Rosenau (1986). Initially, $4.0 \mathrm{~g}$ of 1- to 2-mm airdried aggregates were wetted with distilled water under suction. Then, the wet soil was sieved for $3 \mathrm{~min}$ in a wet-sieving apparatus $(250-\mu \mathrm{m}$ mesh; stroke length of $13 \mathrm{~mm}$; frequency of 35 cycles/min) using distilled water. Subsequently, the aggregates that remained stable were sieved (or even crushed after the prescribed 5-min sieving time) in a dispersing solution (2 g sodium hexametaphosphate/L), until only the coarse matter remained in the sieve. Then, all the obtained fractions were dried at $105^{\circ} \mathrm{C}$.

The stable fraction is equal to the weight of soil sieved in the dispersing solution divided by the sum of the weights sieved during both the steps. The proportion of aggregated soil was corrected for coarse matter.

\section{Ponding infiltrometer runs}

Single ring infiltrometer tests were conducted using the device designed by Di Prima (2015). This device allows to maintain a small constant water head on a soil surface confined by a ring using a Mariotte bottle for water supply (Figure 3 ). The device is equipped with a differential pressure transducer

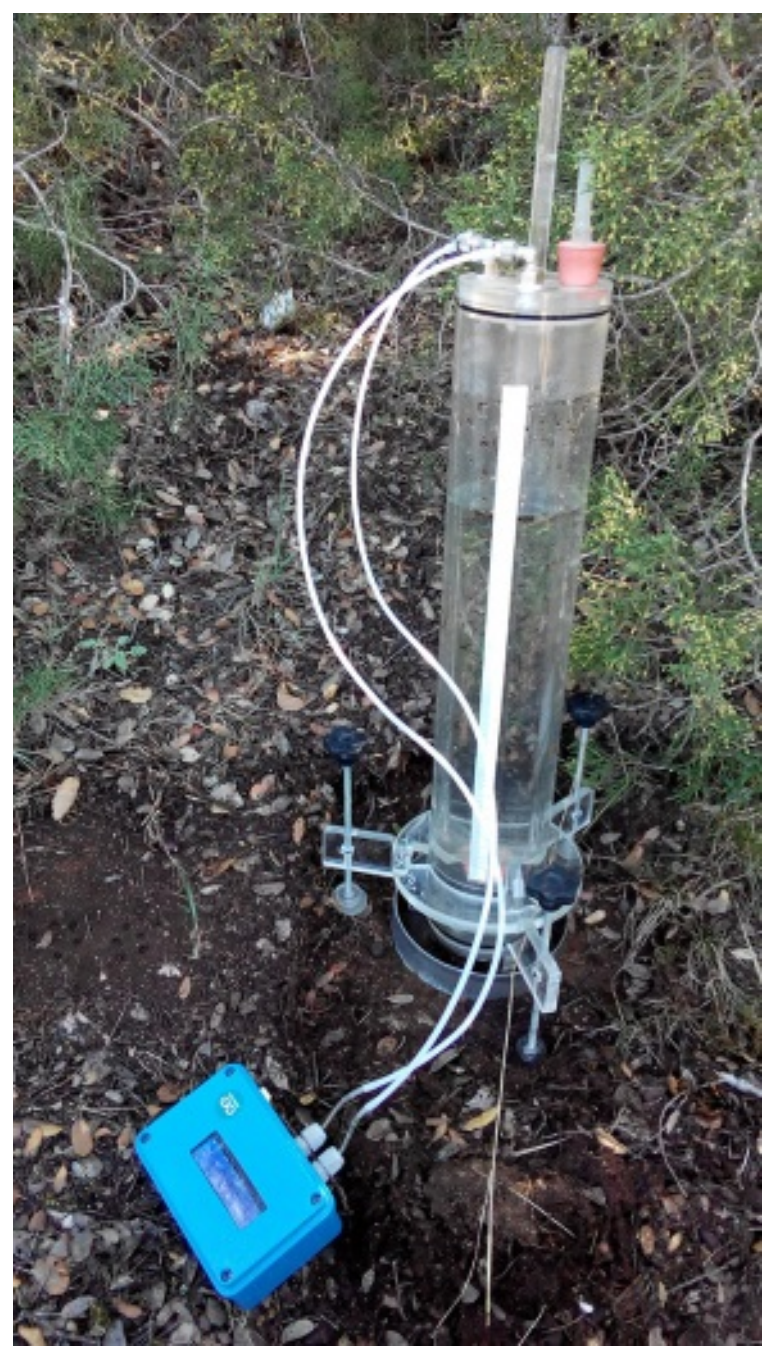

Fig. 3. Compact automated infiltrometer proposed by Di Prima (2015). The device consists of a containment ring with a small head of water that is controlled by a Mariotte reservoir and a data acquisition system based on the open source microcontroller platform Arduino.

and an automatic data acquisition system that increases measurement speed and permits measurement at short time intervals thus allowing measurements of cumulative infiltration under very small water ponded depth (i.e., of the order of few $\mathrm{mm}$ ) with high precision (Di Prima et al., 2016).

In this investigation, a ring with an inner diameter of 150 $\mathrm{mm}$ was inserted to a depth of $10 \mathrm{~mm}$. A constant depth of ponding $(\leq 10 \mathrm{~mm})$ was then established and flow rate was monitored until the reservoir of the device emptied, allowing detection of quasi steady state conditions. To minimize disturbance of the soil surface and to have an accurate data acquisition from the beginning of the run, the water head was initially applied on a thin plastic film positioned on the soil surface inside the ring (Di Prima, 2015). After that water was discharged from the base outlet, through lifting a piston, data acquisition was started. Infiltration started when the plastic film was removed. When the water level in the ring went down, the Mariotte bottle provided a certain amount of water to the ring. At this moment, some bubbles could be seen through the bottle from the air entry tube, leading to outliers which can easily be identified and eliminated. Avoiding the direct detachment of the bubbles from the bottom outlet allowed to minimize 
turbulence which could affect the soil surface. Between two consecutive water supplies, the height of water in the reservoir remains constant which results in a step-shaped water level vs. time relationship. The cumulative infiltration curve is deduced by sampling the water levels at the time immediately preceding each bubble detachment. At this time, the previous volume poured inside the ring has completely infiltrated (Di Prima, 2015).

The method developed by $\mathrm{Wu}$ et al. (1999), referred to as 'Method 2' in their paper, was applied to calculate $K_{s}\left(\mathrm{~mm} \mathrm{~h}^{-1}\right)$, for each infiltration run. This choice was made because this method is based on a generalized solution for single ring infiltrometers that also works when the ponded depth of water on the soil surface is close to zero (Wu and Pan, 1997). The calculation procedure by $\mathrm{Wu}$ et al. (1999) makes use of the steady state phase of the infiltration process, and it requires an estimate of the so-called $\alpha^{*}$ parameter, equal to the ratio between $K_{s}$ and the field-saturated soil matric flux potential. In this investigation, a value of $\alpha^{*}=0.036 \mathrm{~mm}^{-1}$ was considered as suggested by Elrick and Reynolds (1992) for highly structured soils.

\section{RESULTS AND DISCUSSION Statistical distribution of the data}

According to the Lilliefors (1967) test, the hypothesis of normal distribution of both the untransformed and the $\log$-transformed data was generally not rejected $(\mathrm{p}=0.05)$ for the considered datasets (Table 2). The only exception was the WDPT data of the control plot since the normal distribution hypothesis of the untransformed data was rejected in this case. However, the largest difference between the cumulative empirical frequency distribution and the corresponding theoretical function was generally smaller with reference to the log-transformed data. Therefore, the variables were assumed to be log-normally distributed, and geometric means and associated CV were calculated using the appropriate "lognormal equations" (Lee et al., 1985). Consequently, the relationships between the WDPT, $R, K_{-20}$ and $K_{s}$ data were analyzed using the non-parametric Spearman rank correlation analysis, $r$ (SAS Institute Inc., 1999), instead of usual parametric tests.
Table 2. Results of the Lilliefors (1967) test for each variable, in the control and thinned plots.

\begin{tabular}{|c|c|c|c|c|c|}
\hline \multirow[t]{2}{*}{ Variable } & \multirow[t]{2}{*}{ Plot } & \multirow[t]{2}{*}{ Sample size } & \multicolumn{2}{|c|}{$D_{\max }$} & \multirow[t]{2}{*}{$D_{\text {crit }}$} \\
\hline & & & $\mathrm{N}$ & $\mathrm{LN}$ & \\
\hline WDPT (s) & $\mathrm{C}$ & 8 & 0.290 & 0.169 & 0.285 \\
\hline WDPT (s) & $\mathrm{T}$ & 8 & 0.208 & 0.173 & 0.285 \\
\hline$R(-)$ & $\mathrm{C}$ & 7 & 0.290 & 0.162 & 0.300 \\
\hline$R(-)$ & $\mathrm{T}$ & 6 & 0.160 & 0.103 & 0.319 \\
\hline$K_{-20}\left(\mathrm{~mm} \mathrm{~h}^{-1}\right)$ & $\mathrm{C}$ & 7 & 0.138 & 0.135 & 0.300 \\
\hline$K_{-20}\left(\mathrm{~mm} \mathrm{~h}^{-1}\right)$ & $\mathrm{T}$ & 5 & 0.180 & 0.121 & 0.337 \\
\hline$K_{s}\left(\mathrm{~mm} \mathrm{~h}^{-1}\right)$ & $\mathrm{C}$ & 8 & 0.264 & 0.126 & 0.285 \\
\hline$K_{s}\left(\mathrm{~mm} \mathrm{~h}^{-1}\right)$ & $\mathrm{T}$ & 8 & 0.181 & 0.071 & 0.285 \\
\hline
\end{tabular}

WDPT $=$ water drop penetration time; $R=$ index of water repellency; $K_{-20}=$ unsaturated hydraulic conductivity; $K_{s}=$ saturated soil hydraulic conductivity; $C=$ control plot; $T=$ thinned plot; $D_{\max }=$ largest difference between the empirical cumulative distribution function and the corresponding theoretical function (smaller values are given in bold); $D_{\text {crit }}=$ critical value of $D_{\max } ; \mathrm{N}=$ normal; $\mathrm{LN}=$ log-normal.

\section{Comparison between thinned and control plots}

Soil bulk density, antecedent soil water content and organic carbon content did not differ significantly between the $\mathrm{T}$ and $\mathrm{C}$ plots according to a two-tailed t test at $p=0.05$ (Table 3).

Small differences were detected with reference to WSA $(-4.4 \%)$ but in this case they were statistically significant since variability of WSA was low at both plots.

The $\mathrm{T}$ and $\mathrm{C}$ plots had statistically similar WDPT, $R, K_{-20}$ and $K_{s}$ values (Table 3 ). However, the results for the water repellency indices (WDPT and $R$, Figures $4 \mathrm{a}, \mathrm{b}$ ) were not perfectly similar to the soil hydraulic conductivity results $\left(K_{-20}\right.$ and $K_{s}$, Figure $4 \mathrm{c}$ ). In particular, the T plot had a three times higher $R$ value and a ten times higher WDPT value than the $\mathrm{C}$ plot.

Moreover, the lowest WDPT and both the lowest and the highest $R$ index were higher in the T plot as compared with the $\mathrm{C}$ plot (Figures $4 \mathrm{a}, \mathrm{b}$ ). Therefore, the two independent experimental methods consistently suggested that soil was more water repellent at the $\mathrm{T}$ site but the low number and the high variability of the data $(\mathrm{CV} \geq 155 \%)$, especially with reference to the WDPT datasets, impeded to give statistical support to this finding.

Table 3. Sample size $(\mathrm{N})$, minimum (min), maximum (max), mean, and coefficient of variation (CV, in \%) of the dry bulk density, $\rho_{b}\left(\mathrm{~g} \mathrm{~cm}^{-3}\right)$, initial volumetric soil water content, $\theta_{0}\left(\mathrm{~cm}^{3} \mathrm{~cm}^{-3}\right)$, organic carbon content, TOC $\left(\mathrm{g} \mathrm{kg}^{-1}\right)$, water stable aggregate $>0.250 \mathrm{~mm}$, WSA (\% of soil weight), water drop penetration time, WDPT (s), index of water repellency, $R(-)$, unsaturated hydraulic conductivity, $K_{-20}\left(\mathrm{~mm} \mathrm{~h}^{-1}\right)$, and saturated soil hydraulic conductivity, $K_{s}\left(\mathrm{~mm} \mathrm{~h}^{-1}\right)$, in the control and thinned plots.

\begin{tabular}{llllllllll}
\hline Treatment & Statistic & $\rho_{b}$ & $\theta_{0}$ & TOC & WSA & WDPT & $R$ & $K_{-20}$ & $K_{s}$ \\
\hline Thinned & $\mathrm{N}$ & 8 & 9 & 9 & 8 & 8 & 6 & 5 & 8 \\
& $\min$ & 0.798 & 0.074 & 77.9 & 83.7 & 30 & 2.9 & 0.2 & 168.4 \\
& $\max$ & 1.167 & 0.242 & 185.8 & 95.3 & 3600 & 54.9 & 2.8 & 2438.9 \\
& mean & $1.014 \mathrm{a}$ & $0.139 \mathrm{a}$ & $109.8 \mathrm{a}$ & $91.1 \mathrm{a}$ & $543 \mathrm{a}$ & $13.8 \mathrm{a}$ & $0.6 \mathrm{a}$ & $669.6 \mathrm{a}$ \\
& $\mathrm{CV}$ & 12 & 35.8 & 30.5 & 5.2 & 714.2 & 155.5 & 66.8 & 102.0 \\
\hline Control & $\mathrm{N}$ & 10 & 10 & 9 & 8 & 8 & 7 & 7 & 8 \\
& $\min$ & 0.773 & 0.089 & 64.5 & 93.2 & 1 & 0.9 & 0.1 & 270.9 \\
& max & 1.247 & 0.179 & 173.7 & 97.8 & 3600 & 39.8 & 8.6 & 2604.5 \\
& mean & $1.046 \mathrm{a}$ & $0.135 \mathrm{a}$ & $97.4 \mathrm{a}$ & $95.3 \mathrm{~b}$ & $53 \mathrm{a}$ & $4.3 \mathrm{a}$ & $1.4 \mathrm{a}$ & $666.3 \mathrm{a}$ \\
& $\mathrm{CV}$ & 15 & 26.0 & 33.3 & 1.7 & 7427.6 & 217.6 & 78.7 & 75.0 \\
\hline
\end{tabular}

For a given variable, the values in a column followed by the same lower case letter were not significantly different according to a two tailed $\mathrm{t}$ test $(p=0.05)$. 

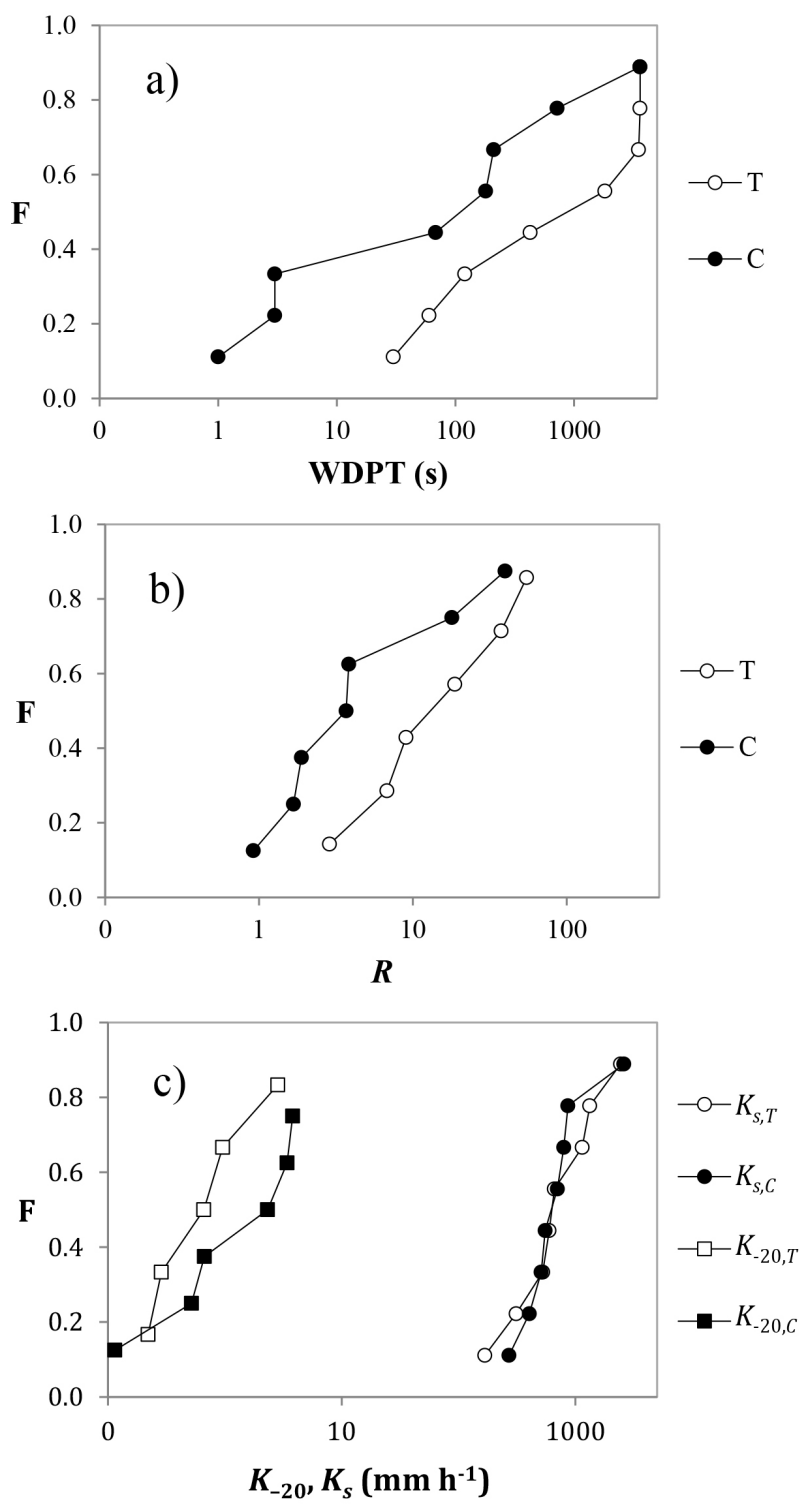

Fig. 4. Cumulative empirical frequency distribution of the (a) water drop penetration time, WDPT (s), (b) index of water repellency, $R$ $(-)$, and (c) saturated, $K_{s}\left(\mathrm{~mm} \mathrm{~h}^{-1}\right)$, and unsaturated, $K_{-20}\left(\mathrm{~mm} \mathrm{~h}^{-1}\right)$, soil hydraulic conductivity for the Thinned (T) and Control (C) plots.

On the other hand, variability of soil hydraulic conductivity was in line with that documented for this variable (e.g., Warrick, 1998), and the mean values of soil hydraulic conductivity collected in the two plots differed at the most by a factor of 2.3 , that could be considered practically negligible for many hydrological applications (Elrick and Reynolds, 1992).

To better interpret the comparison between repellency indices at the two plots, it should be considered that Bautista et al. (2015) reported an increasing content of soluble nitrogen in the passage from the $\mathrm{C}$ plot to the $\mathrm{T}$ one at the study site $(2.63$ and $3.20 \mathrm{mg} \mathrm{L}^{-1}$, respectively). The greater availability of nitrogen in the thinned plot likely increased microbial activity and, consequently, production of water repellent substances (Hallett and Young, 1999; Roberson et al., 1995). In other terms, the investigation by Bautista et al. (2015) suggested that the input of organic matter as a consequence of the addition of plant residues after the thinning treatment could be effective in determining the observed higher levels of water repellency in the $\mathrm{T}$ plot.
According to different authors, higher water repellency values may result in higher fractions of water-stable aggregates (Capriel et al., 1995; Doerr et al., 2000; Giovannini and Lucchesi, 1983; Rawitz and Hazan, 1978). However, in our investigation, higher WSA values were obtained in the C plot, despite the lower values of water repellency measured in this plot. This result is probably due to the differences in the nitrogen content between the plots (Bautista et al., 2015). More nitrogen is expected to imply an enhanced ability of micro-organisms to decompose polysaccharides or other carbon-rich compounds (Skinner, 1979) that bind soil particles together, thus leading to lower aggregate stability. Briefly, micro-organisms are expected to decrease aggregate stability by degrading organics that bind particles all together and produce water repellent molecules, at the same time.

\section{Relationships between infiltration-based variables}

Taking into account that data were collected in two contiguous plots with the same texture and similar $\rho_{\mathrm{b}}, \theta_{0}$ and TOC values at the time of sampling (Table 3 ), all data were analyzed together to check relationships between infiltration-based variables (i.e., $R$, WDPT, $K_{s}, K_{-20}$ ) at the field site.

Despite the limited sample size $(\mathrm{N}=13)$ and the very different variability of the individual WDPT and $R$ values (Table 3), the correlation between these two variables was significant $(r=$ $0.75, p<0.05$ ) (Table 4 and Figure 5). This result confirmed the usefulness of both the applied methods to assess soil water repellency. In particular, our investigation supported previous findings by Lichner et al. (2007), who showed that the minidisk infiltrometer may successfully be applied for estimating the index of water repellency over a wide range of water repellent conditions (from $R=0.9$ to 54.9 in this investigation) (Table 3 ).

Infiltration rates measured with the single ring infiltrometer with a small ponded head of water $(\leq 10 \mathrm{~mm})$ were two orders of magnitude greater than infiltration rates measured at $-20 \mathrm{~mm}$ (1417 and $14 \mathrm{~mm} \mathrm{~h}^{-1}$, respectively). Differences of this order of magnitude or even higher between saturated and near-saturated infiltration rates were often observed in various macroporous soils (Buczko et al., 2003; Dunn and Phillips, 1991; Watson and Luxmoore, 1986).

The $K_{-20}$ values showed a negative correlation with both WDPT and $R$ (Spearman-rank correlation coefficient equal to 0.88 and -0.76 , respectively) (Figure 6) while $K_{s}$ values did not (Table 4). Therefore, water repellency at a sampling point clearly influenced the unsaturated soil hydraulic conductivity but not the saturated soil hydraulic conductivity. Probably, this result occurred because macropore flow, not affected by water repellency, contributed appreciably to determine soil water transport processes under ponding conditions.

Table 4. Spearman correlation coefficients, $r$, of the measured properties.

\begin{tabular}{lllll}
\hline & WDPT (s) & $R(-)$ & $K_{-20}\left(\mathrm{~mm} \mathrm{~h}^{-1}\right)$ & $K_{s}\left(\mathrm{~mm} \mathrm{~h}^{-1}\right)$ \\
\hline WDPT (s) & 1 & & & \\
$R(-)$ & $\mathbf{0 . 7 5}$ & 1 & & \\
$K_{-20}\left(\mathrm{~mm} \mathrm{~h}^{-1}\right)$ & $\mathbf{- 0 . 8 8}$ & $-\mathbf{0 . 7 6}$ & 1 & \\
$K_{s}\left(\mathrm{~mm} \mathrm{~h}^{-1}\right)$ & -0.23 & 0.18 & 0.13 & 1 \\
\hline
\end{tabular}

WDPT $=$ water drop penetration time; $R=$ index of water repellency; $K_{-20}=$ unsaturated hydraulic conductivity; $K_{s}=$ saturated soil hydraulic conductivity.

Correlations that are significant $(p<0.05)$ are given in bold. 


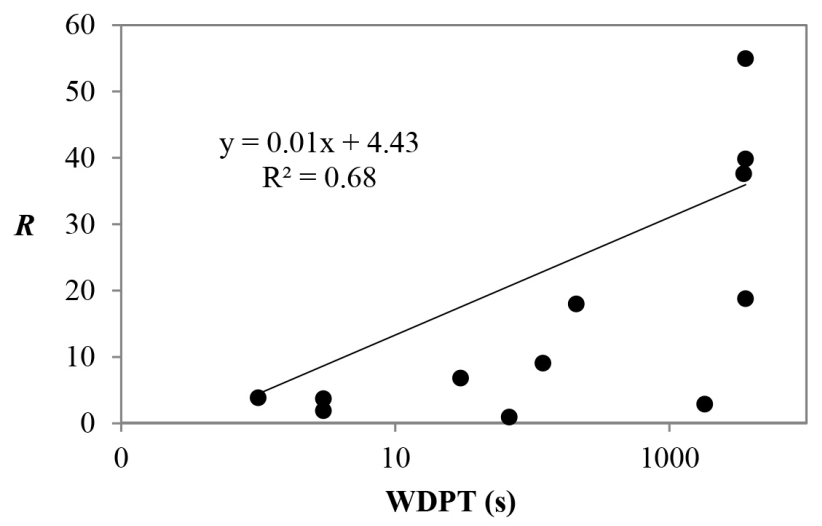

Fig. 5. Comparison between the water drop penetration time, WDPT (s), and the index of water repellency, $R(-)$.

The geometric mean of $K_{s}\left(668.0 \mathrm{~mm} \mathrm{~h}^{-1}\right)$ was more than two orders of magnitude higher than the geometric mean of $K_{-20}$ $\left(1.0 \mathrm{~mm} \mathrm{~h}^{-1}\right)$. Even higher $K_{s}$ values have been reported in the literature for other forest soils (e.g., Buczko et al., 2006; Pirastru et al., 2014). For instance, Gonzalez-Sosa et al. (2010) obtained, with a single ring infiltrometer with a large radius to catch macropores $(20 \mathrm{~cm})$, a mean $K_{s}$ value of $5400 \mathrm{~mm} \mathrm{~h}^{-1}$. Higher values were also measured by Buczko et al. (2006), who used a ponded ring infiltrometer in a study on soil water repellence in a podzolized Cambisol with mainly sandy particles under a pine-beech forest.

Therefore, ponding and tension infiltration experiments provided a complementary information about saturated and nearsaturated hydraulic conductivity of the soil. In other words, they highlighted a clear increase of the hydraulic conductivity when moving from near-saturated $(-20 \mathrm{~mm}$ of water pressure head) to saturated conditions. This difference can be explained by the activation of macroporosity (Lassabatere et al., 2014), and the high organic matter content (Table 3), which has implication on the maintenance of soils structure (Ruiz-Colmenero et al., 2013), and also to the presence of high root and soil fauna density and activity (Beven and Germann, 1982; Gonzalez-Sosa et al., 2010). The ratio between saturated and near-saturated soil hydraulic conductivity reported by Gonzalez-Sosa et al. (2010) on a small French suburban catchment with mainly sandy loam soils was approximately 50 . Therefore, this investigation yielded consistent results with the literature. Moreover, the water repellent behavior of the soil likely contributed to increase this ratio. The reason was that soil water repellency was found to reduce the measured conductivity under unsaturated conditions while it did not affect the saturated conductivity measurements. Probably, this difference between unsaturated and saturated infiltration measurements occurred because the water-entry values for repellent soils are positive (Wang et al., 1998) and an initially repellent soil is not wetted until a critical water-entry value, which may be of the order of some centimeters, is reached (Wang et al., 2000). For instance, Reynolds et al. (2000) found that the $K_{s}$ values obtained with the pressure infiltrometer were significantly higher than those derived by the tension infiltrometer, especially in forest soils that commonly developed water repellency. The excavation of the area at the end of the infiltration runs revealed a less thorough soil wetting when a negative pressure head was applied. As suggested by Buczko et al., (2006), this observation may contribute to explain the large difference between $K_{s}$ and $K_{-20}$. In fact, MDI measurements may not wet entirely the soil due to the hetero-
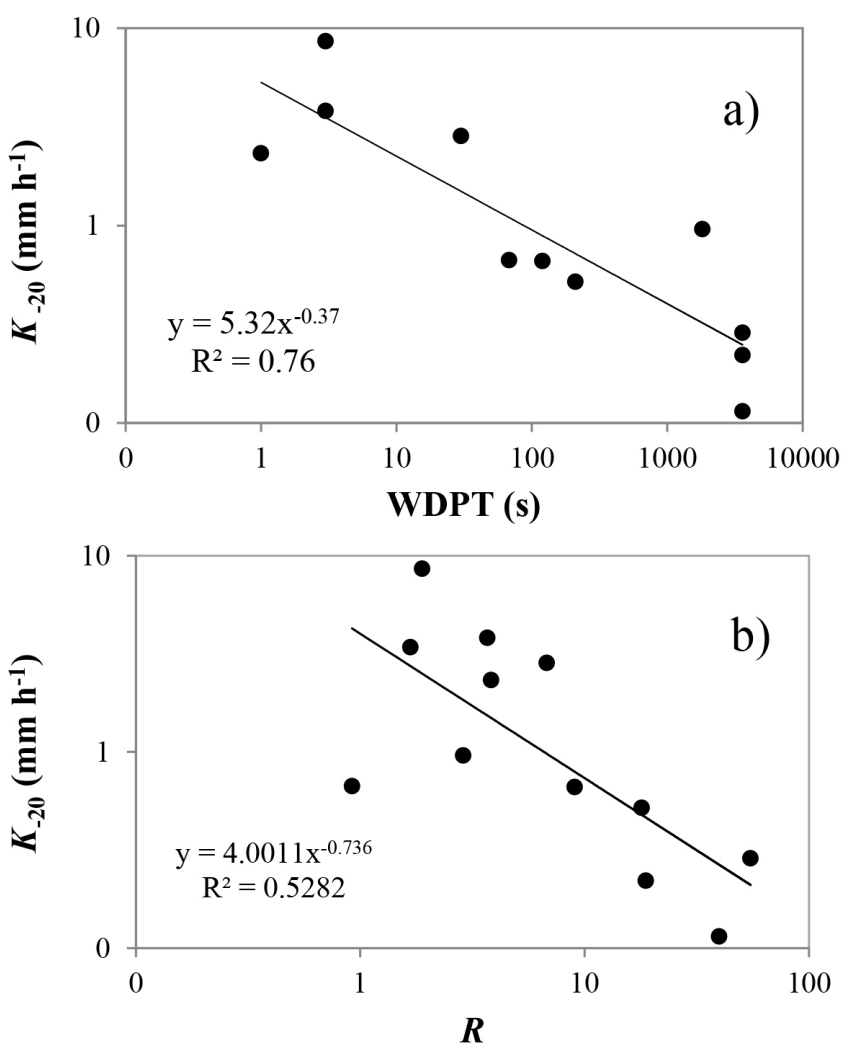

Fig. 6. Comparison between the unsaturated soil hydraulic conductivity, $K_{-20}\left(\mathrm{~mm} \mathrm{~h}^{-1}\right)$, (a) the water drop penetration time, WDPT (s), and (b) the index of water repellency, $R(-)$.

geneity of water repellency at the millimeter to centimeter scale (Buczko and Bens, 2006).

Nyman et al. (2010) reported increasing hydraulic conductivity values as the hydraulic head increased under both repellent and non-repellent conditions. However, in water repellent soils, this phenomenon probably also represents the effect of increased saturation and enhanced contribution by already active macropores. In other words, the increase in flow could be caused by initiation of flow through pore size classes where the hydraulic head exceeded the entry pressure head.

The automatic infiltrometer device used in this investigation allowed to maintain a small water head on the soil surface, and this experimental approach seems useful to study the infiltration process in macroporous repellent soils. In fact, a few $\mathrm{mm}$ ponded head of water, hence, lower than the commonly waterentry values for repellent soils (Wang et al., 1998), could allow the operator to characterize water infiltration occurring through either structural or other gaps in the water repellent layer or as 'fingered flow' through zones of hydrophilic or less water repellent soil (Doerr et al., 2000). At the same time, the maintenance of the hydrophobic behavior during the early stage of the ponding experiments, due to the small imposed water head, was shown by the convex shape of the cumulative infiltration curve, which is specific for hydrophobic soils (Di Prima et al., 2016; Lassabatere et al., 2013). Therefore, ponding runs with a small water head avoided to overwhelm soil water repellency (Nyman et. al., 2010).

The similarity of the $\mathrm{T}$ and $\mathrm{C}$ plots in terms of both $K_{s}$ and $K_{-20}$ suggested that thinning had no negative implication on vertical water fluxes at the soil surface. 


\section{CONCLUSIONS}

Soil water repellency, water-stable aggregates and unsaturated and saturated soil hydraulic conductivity were determined by simple and low-cost methods in two contiguous plots, one of them thinned reducing the forest density from 861 to 414 tree per ha.

The input of organic matter as a consequence of the addition of plant residues after the thinning treatment resulted in a slightly stronger repellent behavior at the thinned plot. The presence of a significant macropore network, high root and soil fauna density and activity and water repellent behavior of the soil determined a sharp increase of the hydraulic conductivity when moving from near-saturated to saturated conditions for both tinned and control plots.

Our measurements demonstrated that thinning had no a negative implication on saturated and unsaturated hydraulic conductivities and on vertical water fluxes at the soil surface. These findings could be helpful for predicting the changes in soil hydraulic properties and in the near-surface hydrological processes in similar Mediterranean environments where the canopy has been opened. These results must be taken into consideration when developing models for water field evaluation.

Ponding experiments, carried out with a very small head of water allowed to properly characterizing water infiltration on water repellent soils with relevant macroporosity. Therefore, the new automated infiltrometer could be considered as an efficient and easy-to-use device to characterize water infiltration at the surface even in water repellent soils, usually considered as very challenging.

Acknowledgements. We thank S. Cullotta for his passion as researcher and mentor during all his career. This study is a part of research projects: "Indagini sperimentali per la simulazione dei processi di formazione del deflusso superficiale nei suoli boscati, Progetto FIRB 2012 - MIMOSE", "CGL2011-28776C02-02, HYDROSIL", and "CGL2014-58127-C3-2, SILWAMED". In particular, the last two research projects were funded by the Spanish Ministry of Science and Innovation and FEDER funds. SDP also thanks A.K., V.A. \& D.U.

\section{REFERENCES}

Alonso-Sarría, F., Martínez-Hernández, C., Romero-Díaz, A., Cánovas-García, F., Gomariz-Castillo, F., 2016. Main environmental features leading to recent land abandonment in Murcia region (Southeast Spain). Land Degrad. Develop., 27, 654-670. DOI: 10.1002/ldr.2447.

Angulo-Jaramillo, R., Vandervaere, J.-P., Roulier, S., Thony, J.-L., Gaudet, J.-P., Vauclin, M., 2000. Field measurement of soil surface hydraulic properties by disc and ring infiltrometers: A review and recent developments. Soil and Tillage Research, 55, 1-29. DOI: 10.1016/S0167-1987(00)00098-2.

Angulo-Jaramillo, R., Bagarello, V., Iovino, M., Lassabatère, L., 2016. Infiltration Measurements for Soil Hydraulic Characterization. Springer International Publishing.

Aussenac, G., Granier, A., 1988. Effects of thinning on water stress and growth in Douglas-fir. Canadian Journal of Forest Research, 18, 100-105. DOI: 10.1139/x88-015.

Bachmann, J., Woche, S.K., Goebel, M.-O., Kirkham, M.B., Horton, R., 2003. Extended methodology for determining wetting properties of porous media. Water Resour. Res. 39, 1353. DOI: $10.1029 / 2003$ WR002143.

Bagarello, V., Di Prima, S., Iovino, M., Provenzano, G., 2014. Estimating field-saturated soil hydraulic conductivity by a simplified Beerkan infiltration experiment. Hydrological Processes, 28, 1095-1103. DOI:10.1002/hyp.9649.

Bautista, I., Pabón, C., Lull, C., González-Sanchís, M., Lidón, A., del Campo, A., 2015. Efectos de la gestión forestal en los flujos de nutrientes asociados al ciclo hidrológico en un bosque mediterráneo de Quercus Ilex. Cuadernos de la Sociedad Española de Ciencias Forestales, 41, 343-354.

Benito Rueda, E., Rodríguez-Alleres, M., Varela Teijeiro, E., 2016. Environmental factors governing soil water repellency dynamics in a Pinus Pinaster plantation in NW Spain. Land Degrad. Develop., 27, 719-728. DOI:10.1002/1dr.2370

Bens, O., Wahl, N.A., Fischer, H., Hüttl, R.F., 2006. Water infiltration and hydraulic conductivity in sandy cambisols: impacts of forest transformation on soil hydrological properties. Eur. J. Forest Res., 126, 101-109. DOI: 10.1007/s10342-006-0133-7.

Beven, K., Germann, P., 1982. Macropores and water flow in soils. Water Resour. Res., 18, 1311-1325. DOI: 10.1029/WR018i005p01311.

Bisantino, T., Bingner, R., Chouaib, W., Gentile, F., Trisorio Liuzzi, G., 2015. Estimation of runoff, peak discharge and sediment load at the event scale in a medium-size Mediterranean watershed using the Annagnps Model. Land Degrad. Develop., 26, 340-355. DOI:10.1002/ldr.2213.

Blanco-Canqui, H., Lal, R., Shipitalo, M.J., 2007. Aggregate disintegration and wettability for long-term management systems in the Northern Appalachians. Soil Science Society of America Journal, 71, 759. DOI:10.2136/sssaj2006.0001.

Blanco-Canqui, H., Lal, R., 2009. Extent of soil water repellency under long-term no-till soils. Geoderma, 149, 171-180. DOI: 10.1016/j.geoderma.2008.11.036.

Bodí, M.B., Muñoz-Santa, I., Armero, C., Doerr, S.H., MataixSolera, J., Cerdà, A., 2013. Spatial and temporal variations of water repellency and probability of its occurrence in calcareous Mediterranean rangeland soils affected by fires. Catena, 108, 14-25. DOI: 10.1016/j.catena.2012.04.002.

Brooks, K.N., Folliott, P.F., Gregersen, H.M., DeBano, L.F., 2003. Hydrology and the Management of Watersheds. 3rd Ed. Wiley-Blackwell, Ames, 574 p.

Buczko, U., Bens, O., 2006. Assessing soil hydrophobicity and its variability through the soil profile using two different methods. Soil Science Society of America Journal, 70, 718727. DOI: 10.2136/sssaj2005.0183.

Buczko, U., Benz, O., Hangen, E., Brunotte, J., Huttl, R., 2003. Infiltration and macroporosity of a silt loam soil under two contrasting tillage systems. Landbauforschung Volkenrode 53, 181-190.

Buczko, U., Bens, O., Hüttl, R.F., 2006. Water infiltration and hydrophobicity in forest soils of a pine-beech transformation chronosequence. Journal of Hydrology, 331, 383-395. DOI: 10.1016/j.jhydrol.2006.05.023.

Cammeraat, E.L.H., Cerdà, A., Imeson, A.C., 2010. Ecohydrological adaptation of soils following land abandonment in a semi-arid environment. Ecohydrol., 3, 421-430. DOI: 10.1002/eco.161.

Capriel, P., Beck, T., Borchert, H., Gronholz, J., Zachmann, G., 1995. Hydrophobicity of the organic matter in arable soils. Soil Biology and Biochemistry, 27, 1453-1458. DOI: 10.1016/0038-0717(95)00068-P.

Cerdà, A., 1996. Seasonal variability of infiltration rates under contrasting slope conditions in southeast Spain. Geoderma, 69, 217-232. DOI: 10.1016/0016-7061(95)00062-3.

Cerdà, A., 1997. Seasonal changes of the infiltration rates in a Mediterranean scrubland on limestone. Journal of Hydrology, 198, 209-225. DOI: 10.1016/S0022-1694(96)03295-7. 
Cerdà, A., 1999. Simuladores de lluvia y su aplicación a la Geomorfologia: estado de la cuestión. [A review of the rainfall simulators and its applications to the Geomorphology]. Cuadernos de investigación geográfica, 25, 45-84. doi:http://dx.doi.org/10.18172/cig.1036

Cerdà, A., Doerr, S.H., 2007. Soil wettability, runoff and erodibility of major dry-Mediterranean land use types on calcareous soils. Hydrol. Process., 21, 2325-2336. DOI: 10.1002/hyp.6755.

Decagon Devices Inc., 2014. Minidisk Infiltrometer User's Manual. Decagon Devices, Inc., Pullman, USA 24.

Dekker, L.W., Doerr, S.H., Oostindie, K., Ziogas, A.K., Ritsema, C.J., 2001. Water repellency and critical soil water content in a dune sand. Soil Science Society of America Journal, 65, 1667-1674. DOI: 10.2136/sssaj2001.1667.

DeBano, L.F., 1981. Water repellent soils: a state-of-the-art. US Department of Agriculture, Forest Service, Pacific Southwest Forest and Range Experiment Station.

del Campo, A.D., Fernandes, T.J.G., Molina, A.J., 2014. Hydrology-oriented (adaptive) silviculture in a semiarid pine plantation: How much can be modified the water cycle through forest management? European Journal of Forest Research 133, 879-894. DOI: 10.1007/s10342-014-0805-7.

Di Prima, S., 2015. Automated single ring infiltrometer with a low-cost microcontroller circuit. Computers and Electronics in Agriculture, 118, 390-395. DOI: 10.1016/j.compag.2015.09.022.

Di Prima, S., Lassabatere, L., Bagarello, V., Iovino, M., Angulo-Jaramillo, R., 2016. Testing a new automated single ring infiltrometer for Beerkan infiltration experiments. Geoderma 262, 20-34. DOI: 10.1016/j.geoderma.2015.08.006.

Dlapa, P., Bodí, M.B., Mataix-Solera, J., Cerdà, A., Doerr, S.H., 2013. FT-IR spectroscopy reveals that ash water repellency is highly dependent on ash chemical composition. Catena, 108, 35-43. DOI: 10.1016/j.catena.2012.02.011.

Doerr, S.H., Shakesby, R.A., Walsh, R.P.D., 2000. Soil water repellency: its causes, characteristics and hydrogeomorphological significance. Earth-Science Reviews, 51, 33-65.

Dunn, G.H., Phillips, R.E., 1991. Macroporosity of a welldrained soil under no-till and conventional tillage. Soil Science Society of America Journal, 55, 817-823. DOI: 10.2136/sssaj1991.03615995005500030031x.

Ebel, B.A., Moody, J.A., 2013. Rethinking infiltration in wildfire-affected soils. Hydrol. Process., 27, 1510-1514. DOI: 10.1002/hyp.9696.

Ebel, B.A., Moody, J.A., Martin, D.A., 2012. Hydrologic conditions controlling runoff generation immediately after wildfire. Water Resour. Res., 48, W03529. DOI: 10.1029/2011WR011470.

Ellerbrock, R.H., Gerke, H.H., Bachmann, J., Goebel, M.-O., 2005. Composition of organic matter fractions for explaining wettability of three forest soils. Soil Science Society of America Journal, 69, 57-66. DOI: 10.2136/sssaj2005.0057.

Elrick, D.E., Reynolds, W.D., 1992. Methods for analyzing constant-head well permeameter data. Soil Science Society of America Journal, 56, 320-323. DOI: 10.2136/sssaj1992.03615995005600010052x.

Fernández, C., Vega, J.A., Jiménez, E., Fonturbel, T., 2011. Effectiveness of three post-fire treatments at reducing soil erosion in Galicia (NW Spain). Int. J. Wildland Fire, 20, 104-114.

Gallart, F., Latron, J., Llorens, P., Rabadà, D., 1997. Hydrological functioning of mediterranean mountain basins in Vallce- bre, Catalonia: Some challenges for hydrological modelling. Hydrol. Process., 11, 1263-1272. DOI: 10.1002/(SICI)10991085(199707)11:9<1263::AID-HYP556>3.0.CO;2-W.

García, F.J.M., Dekker, L.W., Oostindie, K., Ritsema, C.J., 2005. Water repellency under natural conditions in sandy soils of southern Spain. Aust. J. Soil Res., 43, 291-296.

García-Moreno, J., Gordillo-Rivero, Á.J., Zavala, L.M., Jordán, A., Pereira, P., 2013. Mulch application in fruit orchards increases the persistence of soil water repellency during a 15years period. Soil and Tillage Research, 130, 62-68. DOI: 10.1016/j.still.2013.02.004.

Gee, G.W., Bauder, J.W., 1986. Particle-size analysis. In: Klute, A. (Ed.): Methods of Soil Analysis. Part 1: Physical and Mineralogical Methods. Soil Science Society of America, American Society of Agronomy, Madison, pp. 383-411.

Giovannini, G., Lucchesi, S., 1983. Effect of fire on hydrophobic and cementing substances of soil aggregates. Soil Science, 136, 231-236.

González-Peñaloza, F.A., Cerdà, A., Zavala, L.M., Jordán, A., Giménez-Morera, A., Arcenegui, V., 2012. Do conservative agriculture practices increase soil water repellency? A case study in citrus-cropped soils. Soil and Tillage Research, 124, 233-239. DOI: 10.1016/j.still.2012.06.015.

González-Sanchis, M., del Campo, A., Bautista, I., Lidón, A., García, A., Llull, C., 2013. Hydrological silviculture effects in a natural Quercus ilex forest. Geophysical Research Abstracts, Vol. 15, EGU2013-313.

González-Sanchis, M., del Campo, A., Lidón, A., Lull, C., Bautista, I., García-Prats, A., Francés, F., 2015. Incorporación de criterios eco-hidrológicos en la gestión forestal: adaptación a la escasez de agua de una masa marginal de encina. Cuadernos de la Sociedad Española de Ciencias Forestales, 41, 211-218.

Gonzalez-Sosa, E., Braud, I., Dehotin, J., Lassabatère, L., Angulo-Jaramillo, R., Lagouy, M., Branger, F., Jacqueminet, C., Kermadi, S., Michel, K., 2010. Impact of land use on the hydraulic properties of the topsoil in a small French catchment. Hydrol. Process., 24, 2382-2399. DOI: 10.1002/hyp.7640.

Hallett, P.D., Young, I.M., 1999. Changes to water repellence of soil aggregates caused by substrate-induced microbial activity. European Journal of Soil Science, 50, 35-40. DOI: 10.1046/j.1365-2389.1999.00214.x.

Hallett, P.D., Baumgartl, T., Young, I.M., 2001. Subcritical water repellency of aggregates from a range of soil management practices. Soil Science Society of America Journal, 65, 184-190.

Heiskanen, J., Mäkitalo, K., 2002. Soil water-retention characteristics of Scots pine and Norway spruce forest sites in Finnish Lapland. Forest Ecology and Management, 162, 137-152. DOI: 10.1016/S0378-1127(01)00503-5.

Hibbert, A.R., 1983. Water yield improvement potential by vegetation management on western rangelands. JAWRA Journal of the American Water Resources Association 19, 375-381. DOI: 10.1111/j.1752-1688.1983.tb04594.x.

Keesstra, S., Bouma, J., Wallinga, J., Tittonell, P., Smith, P., Cerdà, A., Montanarella, L., Quinton, J.N., Pachepsky, Y., van der Putten, W.H., Bardgett, R.D., Moolenaar, S., Mol, G., Jansen, B., Fresco, L.O., 2016a. The significance of soils and soil science towards realization of the United Nations Sustainable Development Goals. Soil, 2, 111-128. DOI: 10.5194/soil-2-111-2016.

Keesstra, S., Wittenberg, L., Maroulis, J., Sambalino, F., Malkinson, D., Cerdà, A., Pereira, P., 2016b. The influence of fire history, plant species and post-fire management on soil 
water repellency in a Mediterranean catchment: The Mount Carmel range, Israel. Catena. DOI: 10.1016/j.catena.2016.04.006.

Kemper, W.D., Rosenau, R.C., 1986. Aggregate stability and size distribution. In: Klute, A. (Ed.): Methods of Soil Analysis. Part 1: Physical and Mineralogical Methods. Soil Science Society of America, American Society of Agronomy, Madison, pp. 425-442.

Lassabatère, L., Angulo-Jaramillo, R., Soria Ugalde, J.M., Cuenca, R., Braud, I., Haverkamp, R., 2006. Beerkan estimation of soil transfer parameters through infiltration experiments-BEST. Soil Science Society of America Journal, 70, 521-532. DOI: 10.2136/sssaj2005.0026.

Lassabatere, L., Angulo-Jaramillo, R., Yilmaz, D., Winiarski, T., 2013. BEST method: Characterization of soil unsaturated hydraulic properties. In: Caicedo et al. (Eds): Advances in Unsaturated Soils. CRC Press, London, 527-532.

Lassabatere, L., Yilmaz, D., Peyrard, X., Peyneau, P.E., Lenoir, T., Šimůnek, J., Angulo-Jaramillo, R., 2014. New analytical model for cumulative infiltration into dual-permeability soils. Vadose Zone J. 13. doi:10.2136/vzj2013.10.0181

Lee, D.M., Elrick, D., Reynolds, W., Clothier, B.E., 1985. A comparison of three field methods for measuring saturated hydraulic conductivity. Canadian Journal of Soil Science, $65,563-573$.

Lichner, L., Hallett, P., Feeney, D., Duugová, O., Šír, M., Tesař, M., 2007. Field measurement of soil water repellency and its impact on water flow under different vegetation. Biologia, 62, 537-541. DOI: 10.2478/s11756-007-0106-4.

Lilliefors, H.W., 1967. On the Kolmogorov-Smirnov test for normality with mean and variance unknown. Journal of the American Statistical Association, 62, 399-402. DOI: 10.1080/01621459.1967.10482916.

Molina, A.J., del Campo, A.D., 2012. The effects of experimental thinning on throughfall and stemflow: A contribution towards hydrology-oriented silviculture in Aleppo pine plantations. Forest Ecology and Management, 269, 206-213. DOI: $10.1016 /$ j.foreco.2011.12.037.

Mollnau, C., Newton, M., Stringham, T., 2014. Soil water dynamics and water use in a western juniper (Juniperus occidentalis) woodland. Journal of Arid Environments, 102, 117-126. DOI: 10.1016/j.jaridenv.2013.11.015.

Moody, J.A., Kinner, D.A., Úbeda, X., 2009. Linking hydraulic properties of fire-affected soils to infiltration and water repellency. Journal of Hydrology, 379, 291-303. DOI: 10.1016/j.jhydrol.2009.10.015.

Nelson, D.W., Sommers, L.E., 1996. Total carbon, organic carbon, and organic matter. In: Sparks, D.L. (Ed.): Methods of Soil Analysis. Part 3: Chemical Methods. Soil Science Society of America, American Society of Agronomy, Madison, pp. 961-1010.

Nyman, P., Sheridan, G., Lane, P.N.J., 2010. Synergistic effects of water repellency and macropore flow on the hydraulic conductivity of a burned forest soil, south-east Australia. Hydrol. Process., 24, 2871-2887. DOI: 10.1002/hyp.7701.

Pereira, P., Cerdà, A., Úbeda, X., Mataix-Solera, J., Arcenegui, V., Zavala, L.M., 2015. Modelling the impacts of wildfire on ash thickness in a short-term period. Land Degrad. Develop., 26, 180-192. DOI: 10.1002/ldr.2195.

Pirastru, M., Niedda, M., Castellini, M., 2014. Effects of maquis clearing on the properties of the soil and on the nearsurface hydrological processes in a semi-arid Mediterranean environment. Journal of Agricultural Engineering, 45, 176. DOI: $10.4081 /$ jae.2014.428.
Prats, S.A., MacDonald, L.H., Monteiro, M., Ferreira, A.J.D., Coelho, C.O.A., Keizer, J.J., 2012. Effectiveness of forest residue mulching in reducing post-fire runoff and erosion in a pine and a eucalypt plantation in north-central Portugal. Geoderma, 191, 115-124. DOI: 10.1016/j.geoderma.2012.02.009.

Rawitz, E., Hazan, A., 1978. The effect of stabilized, hydrophobic aggregate layer properties on soil water regime and seedling emergence. Soil Science Society of America Journal, 42, 787-793. DOI: 10.2136/sssaj 1978.03615995004200050028x.

Reynolds, W.D., Bowman, B.T., Brunke, R.R., Drury, C.F., Tan, C.S., 2000. Comparison of Tension Infiltrometer, Pressure Infiltrometer, and Soil Core Estimates of Saturated Hydraulic Conductivity. Soil Science Society of America Journal, 64, 478-484. DOI:10.2136/sssaj2000.642478x.

Riechers, G.H., Beyers, J.L., Robichaud, P.R., Jennings, K., Kreutz, E., Moll, J., 2008. Effects of three mulch treatments on initial postfire erosion in north-central Arizona. In: Narog, M.G. (Ed.): Proc. 2002 Fire Conf.: Managing Fire and Fuels in the Remaining Wildlands and Open Spaces of the Southwestern United States. Gen. Tech. Rep. PSW-GTR189. U.S. Department of Agriculture, Forest Service, Pacific Southwest Research Station, Albany, CA, pp. 107-113.

Roberson, E.B., Shennan, C., Firestone, M.K., Sarig, S., 1995. Nutritional management of microbial polysaccharide production and aggregation in an agricultural soil. Soil Science Society of America Journal 59, 1587-1594. DOI: 10.2136/sssaj 1995.03615995005900060012x.

Ruiz-Colmenero, M., Bienes, R., Eldridge, D.J., Marques, M.J., 2013. Vegetation cover reduces erosion and enhances soil organic carbon in a vineyard in the central Spain. Catena, 104, 153-160. DOI: 10.1016/j.catena.2012.11.007.

SAS Institute Inc., 1999. SAS/STAT User's Guide, Volume 1, Version 8.2. Cary, NC: Statistical Analysis Systems (SAS) Institute Inc.

Scott, D.F., 2000. Soil wettability in forested catchments in South Africa; as measured by different methods and as affected by vegetation cover and soil characteristics. Journal of Hydrology, 231-232, 87-104. DOI: 10.1016/S00221694(00)00186-4.

Shakesby, R.A., Boakes, D.J., Coelho, C. de O., Gonçalves, A.B., Walsh, R.P., 1996. Limiting the soil degradational impacts of wildfire in pine and eucalyptus forests in Portugal. Applied Geography, 16, 337-355. DOI: 10.1016/01436228(96)00022-7.

Šimon, T., Javůrek, M., Mikanová, O., Vach, M., 2009. The influence of tillage systems on soil organic matter and soil hydrophobicity. Soil and Tillage Research, 105, 44-48. DOI: 10.1016/j.still.2009.05.004.

Skinner, F.A., 1979. Rothamsted studies of soil structure VII. European Journal of Soil Science, 30, 473-481. DOI: 10.1111/j.1365-2389.1979.tb01002.x.

Tillman, R.W., Scotter, D.R., Wallis, M.G., Clothier, B.E., 1989. Water repellency and its measurement by using intrinsic sorptivity. Soil Research, 27, 637-644.

Verheijen, F.G.A., Cammeraat, L.H., 2007. The association between three dominant shrub species and water repellent soils along a range of soil moisture contents in semi-arid Spain. Hydrol. Process., 21, 2310-2316. DOI: 10.1002/hyp.6760.

Wang, Z., Feyen, J., Ritsema, C.J., 1998. Susceptibility and predictability of conditions for preferential flow. Water Resour. Res., 34, 2169-2182. DOI: 10.1029/98WR01761.

Wang, Z., Wu, Q.J., Wu, L., Ritsema, C.J., Dekker, L.W., Feyen, J., 2000. Effects of soil water repellency on infiltra- 
tion rate and flow instability. Journal of Hydrology, 231, 265-276.

Wang, Y., Fan, J., Cao, L., Liang, Y., 2016. Infiltration and runoff generation under various cropping patterns in the Red Soil region of China. Land Degrad. Develop., 27, 83-91. DOI: $10.1002 /$ ldr.2460.

Warrick, A.W., 1998. Spatial variability. In: Hillel, D. (Ed.), Environmental Soil Physics. Academic Press, San Diego, CA, pp. 655-675.

Watson, K.W., Luxmoore, R.J., 1986. Estimating macroporosity in a forest watershed by use of a tension infiltrometer. Soil Science Society of America Journal, 50, 578-582.

Wessel, A.T., 1988. On using the effective contact angle and the water drop penetration time for classification of water repellency in dune soils. Earth Surf. Process. Landforms, 13, 555-561. DOI: 10.1002/esp.3290130609.
Wu, L., Pan, L., 1997. A generalized solution to infiltration from single-ring infiltrometers by scaling. Soil Science Society of America Journal, 61, 1318-1322.

Wu, L., Pan, L., Mitchell, J., Sanden, B., 1999. Measuring saturated hydraulic conductivity using a generalized solution for single-ring infiltrometers. Soil Science Society of America Journal, 63, 788-792. DOI: 10.2136/sssaj1999.634788x.

Zhang, R., 1997. Determination of soil sorptivity and hydraulic conductivity from the disk infiltrometer. Soil Science Society of America Journal 61, 1024-1030. DOI: 10.2136/sssaj 1997.03615995006100040005x.

Zhang, L., Dawes, W.R., Walker, G.R., 2001. Response of mean annual evapotranspiration to vegetation changes at catchment scale. Water Resour. Res. 37, 701-708. DOI: 10.1029/2000WR900325.

Received 9 August 2016 Accepted 16 January 2017 